\title{
Litiasis radiolúcida de Indinavir
}

\author{
L.A. Fariña Pérez, M.C.Martínez, J. dos Santos y J. Cambronero Santos \\ Urología y Radiología. Hospital POVISA, Vigo.
}

Actas Urol Esp. 2005; 29 (1): 120

$\mathrm{E}^{\prime}$ 1 inhibidor de la proteasa Indinavir (Crixi$\operatorname{van}{ }^{\circledR}$ “) es un antiviral para el tratamiento del SIDA que en parte se elimina por la orina, aumentando su solubilidad en orinas ácidas. Alrededor de $10 \%$ de los pacientes que lo toman, pueden tener cólicos renales por cálculos de Indinavir, de consistencia gelatinosa y que se adhieren al uréter causando en ocasiones hidronefrosis moderada o grave. Son radiolúcidos, tanto en la radiografía simple como en la tomografía computarizada, en donde se manifiestan

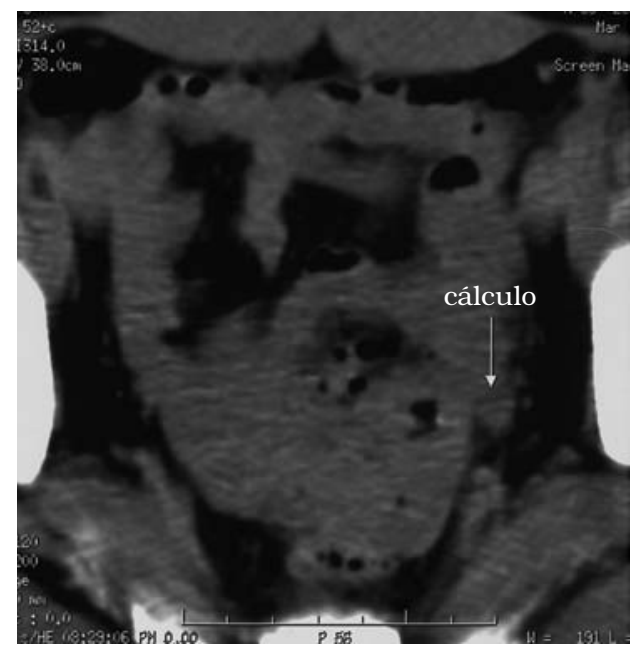

FIGURA I. tomografia computarizada con contraste, la flecha señala el cálculo. como un foco de baja atenuación que podría confundirse con un tumor de uroepitelio. La resonancia magnética puede diferenciarlos, al mostrar imágenes típicas de cálculo (foco de baja densidad rodeado de orina con alta intensidad). En este paciente de 38 años, con cólico de flanco de varias semanas de duración, un cálculo radiolúcido muy blando, de Indinavir puro, del uréter pelviano, que causaba hidronefrosis moderada, fue evacuado mediante ureteroscopia y fragmentación con pinza.

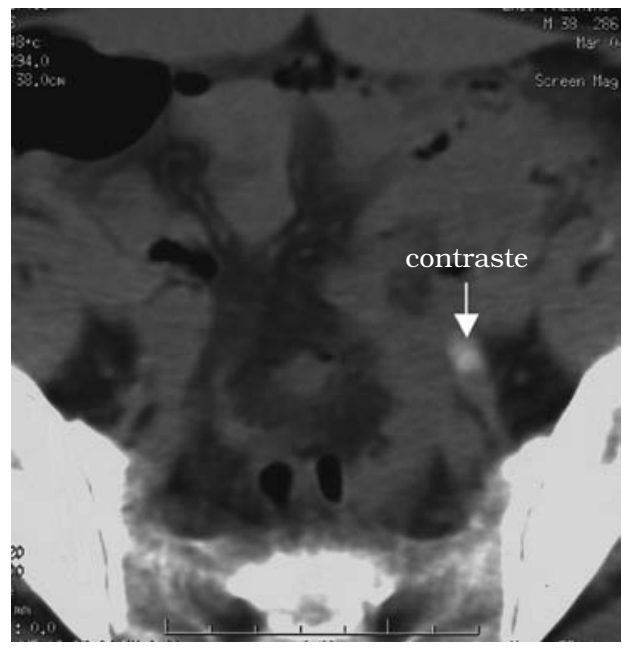

FIGURA 2. en un corte superior, la flecha señala el uréter dilatado con contraste.

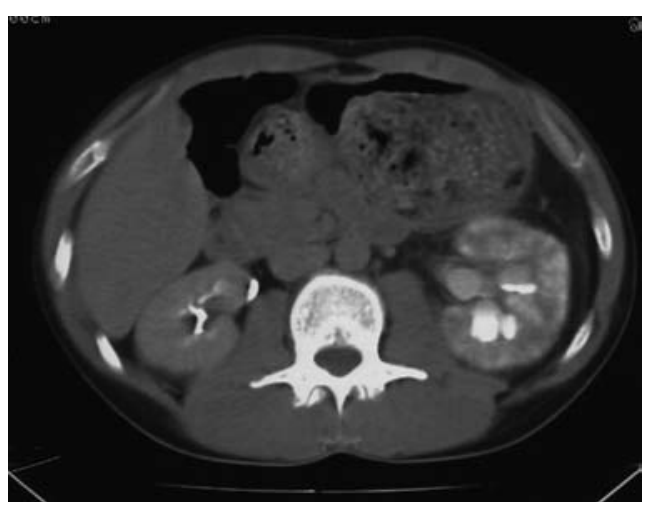

FIGURA 3. hidronefrosis moderada izquierda. 